\title{
Social Program
}

\section{Wednesday, August 18, 2010}

19:00-21:00

Get together

A get together party with entertainment and light refreshments will be held at the Reykjavik Maritime Museum. (Included in the registration fee)

\section{Friday, August 20, 2010}

$18: 30(19: 15)-22: 00$

Banquet at the Blue Lagoon

Price with bath entrance ISK 12.300

Price without bath entrance ISK 10.000

The banquet will be at the Blue Lagoon, which is located approximately $40 \mathrm{~km}$ from Reykjavik.

Transportation will be from Congress hotels at 18:30 for banquet with bath entrance and at 19:15 for banquet without bath entrance.

Congress hotels:

Fosshotel Barón, Fosshotel Lind, Fosshotel Suourgata, Hotel Borg, Hotel Cabin, Hotel Reykjavik, Hotel Centrum, Radisson SAS Hotel Saga. 